JURNAL BASICEDU

Research \& Learning in Elementary Education

https://jbasic.org/index.php/basicedu

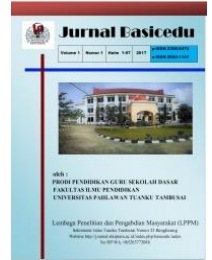

\title{
PENGEMBANGAN ETNOSAINS MULTIMEDIA LEARNING UNTUK MENINGKATKAN KOGNITIF SKILL SISWA SD DI KOTA LUBUKLINGGAU
}

\author{
Tio Gusti Satria ${ }^{1}$, Asep Sukenda Egok $^{2}$ \\ STKIP-PGRI Lubuklinggau, Sumatera Selatan, Indonesia ${ }^{1,2}$ \\ E-mail: satriagustio@gmail.com ${ }^{1}$, asep.egok91@gmail.com ${ }^{2}$
}

\begin{abstract}
Abstrak
Pembelajaran sains yang mampu menjembatani perpaduan antara budaya siswa atau pengetahuan asli dengan budaya ilmiah di sekolah atau pengetahuan khas dari suatu komunitas atau etnosains dapat mengefektifkan proses belajar siswa. Siswa belajar secara formal untuk memahami lingkungannya dengan berbagai permasalahan yang ada di sekitarnya. cara mengajar guru yang sering menggunakan metode ceramah, text book centered dan jarang menggunakan media pembelajaran. Sedangkan, siswa membutuhkan penjelasan dari guru dalam bentuk nyata, akan tetapi karena guru tidak menggunakan media pembelajaran yang dapat menarik minat siswa dalam belajar. media pembelajaran mencakup manusia, materi atau kajian yang membangun suatu kondisi yang membuat siswa mampu memperoleh pengetahuan, keterampilan atau sikap. Media pembelajaran diharapkan untuk menyampaikan atau menyalurkan pesan dari suatu sumber secara terencana kepada siswa, sehingga terjadi lingkungan belajar yang kondusif dimana peserta didik dapat melakukan proses belajar secara efisien dan efektif. Multimedia Learning diharapkan mampu meningkatkan kognitif skill siswa dan pembelajaran menjadi lebih bermakna
\end{abstract}

Kata Kunci: Etnosains, Multimedia Learning, Kognitif Skill

\begin{abstract}
Science learning that is able to bridge the fusion of student culture or original knowledge with scientific culture in schools or unique knowledge from a community or ethnoscience can streamline student learning processes. Students learn formally to understand their environment with various problems around them. how to teach teachers who often use the lecture method, text book centered and rarely use learning media. Meanwhile, students need explanations from the teacher in real form, but because the teacher does not use learning media that can attract students' interest in learning. learning media include humans, materials or studies that build conditions that make students able to obtain knowledge, skills or attitudes. Learning media are expected to deliver or channel messages from a source in a planned manner to students, so that a conducive learning environment occurs where students can carry out the learning process efficiently and effectively. Multimedia Learning is expected to be able to improve students' cognitive skills and learning becomes more meaningful.
\end{abstract}

Keywords: Etnoscience, Multimedia Learning, Cognitive Skills

$\triangle$ Corresponding author :

Address :-

Email : -

ISSN 2580-3735 (Media Cetak)

Phone :- 
14 Pengembangan Etnosains multimedia learning untuk meningkatkan kognitif skill siswa sekolah dasarTio Gusti Satria, Asep Sukenda Egok

\section{PENDAHULUAN}

Pembelajaran sains yang mampu menjembatani perpaduan antara budaya siswa atau pengetahuan asli dengan budaya ilmiah di sekolah atau pengetahuan khas dari suatu komunitas atau etnosains dapat mengefektifkan proses belajar siswa. Siswa belajar secara formal untuk memahami lingkungannya dengan berbagai permasalahan yang ada di sekitarnya. Menurut Henrietta L. (1998) etnosains adalah cabang pengkajian budaya yang berusaha memahami bagaimana pribumi memahami alam mereka. Pribumi biasanya memiliki ideologi dan falsafah hidup yang mempengaruhi mereka mempertahankan hidup. Atas dasar ini, dapat dinyatakan bahwa etnosains merupakan salah satu bentuk etnografi baru (the new ethnography). Melalui etnosains, sebenarnya peneliti budaya justru akan mampu membangun teori yang grass root dan tidak harus mengadopsi teori budaya barat yang belum tentu relevan. Penelitian etnosains terhadap fenomena budaya selalu berbasis etno dan atau folk. Kehadiran etnosains,

Media pembelajaran adalah segala sesuatu yang dapat digunakan untuk menyalurkan pesan sehingga dapat merangsang perhatian, minat, pikiran, dan perasaan pembelajar siswa dalam kegiatan belajar untuk mencapai tujuan pembelajaran tertentu. Media pembelajaran memiliki fungsi yang sangat penting yaitu sebagai pembawa informasi dan pencegah terjadinya hambatan proses pembelajaran, sehingga informasi atau pesan dari komunikator dapat sampai kepada komunikan secara efektif dan efisien. Briggs mendefinisikan media sebagai sarana fisik yang digunakan untuk mengirim pesan kepada peserta didik sehingga merangsang mereka untuk belajar. Pendapat schramm tentang media pembelajaran adalah teknologi pembawa pesan yang dapat dimanfaatkan untuk keperluan pembelajaran (Widodo dan Jasmadi, 2009).
Media yang berupa kombinasi dari teks, foto, seni, grafis, suara, aimasi, dan elemenelemen video yang dimanipulasi secara digital atau disebut juga dengan mutimedia bertujuan untuk menyajikan informasi dalam bentuk yang menyenangkan, menarik, mudah dimengerti, dan jelas. Informasi akan mudah dimengerti karena sebanyak mungkin indera, terutama telinga dan mata, digunakan untuk menyerap informasi tersebut.

Seiring dengan pelaksanaan kurikulum 2013, proses pelaksanaan pembelajaran dilaksanakan secara tematik. Pembelajaran berfokus pada empat Kompetensi Inti salah satunya adalah kompetensi kognitif. Sesuai dengan namanya kognitif adalah sebuah istilah yang digunakan oleh psikolog untuk menjelaskan semua aktifitas mental yang berhubungan dengan persepsi, pikiran, ingatan, dan pengolahan informasi yang memungkinkan seseorang memperoleh pengetahuan, memecahkan masalah, dan merencanakan masa depan, atau semua proses psikogis yang berkaitan dengan bagaimana individu mempelajari, memperhatikan, mengamati, membayangkan, memperkirakan, menilai, dan memikirkan lingkungannya.

Menurut Henrietta L. (1998) etnosains adalah cabang pengkajian budaya yang berusaha memahami bagaimana pribumi memahami alam mereka. Pribumi biasanya memiliki ideologi dan falsafah hidup yang mempengaruhi mereka mempertahankan hidup. Atas dasar ini, dapat dinyatakan bahwa etnosains merupakan salah satu bentuk etnografi baru (the new ethnography).

Pembelajaran sains yang mampu menjembatani perpaduan antara budaya siswa dengan budaya ilmiah di sekolah akan dapat mengefektifkan proses belajar siswa. Siswa akan belajar secara formal untuk memahami 
15 Pengembangan Etnosains multimedia learning untuk meningkatkan kognitif skill siswa sekolah dasarTio Gusti Satria, Asep Sukenda Egok

lingkungannya dengan berbagai permasalahan yang ada di sekitarnya. Di samping itu, pengajaran sains yang berbasis budaya akan sangat relevan dengan konsep pengajaran sains yang direncanakan dalam kurikulum 2013, juga menekankan pada pengembangan nilai spiritual dan sosial. Dengan demikian, pelajaran sains tidak lagi menjadi pelajaran yang asing bagi siswa, berupa hafalan, rumit, tidak ada manfaatnya dan terkesan membosankan, tetapi menjadi pelajaran sains yang bermakna, bermanfaat, dan ramah dengan siswa, karena apa yang mereka pelajari memang benar-benar ada di lingkungan mereka.

Media pembelajaran, menurut Gerlach \& Ely dalam Rayandra Asyhar (2012:7-9), memiliki cakupan yang sangat luas, yaitu termasuk manusia, materi atau kajian yang membangun suatu kondisi yang membuat peserta didik mampu memperoleh pengetahuan, keterampilan atau sikap.

Berdasarkan pengertian tersebut dapat disimpulkan, bahwa media pembelajaran mencakup manusia, materi atau kajian yang membangun suatu kondisi yang membuat peserta didik mampu memperoleh pengetahuan, keterampilan atau sikap. Media Pembelajaran merupakan segala sesuatu yang dapat menyampaikan atau menyalurkan pesan dari suatu sumber secara terencana, sehingga terjadi lingkungan belajar yang kondusif dimana penerimanya dapat melakukan proses belajar secara efisien dan efektif.

Sebagaimana dikemukakan oleh Dony Ariyus (2009:2), bahwa multimedia berasal dari dua kata, yaitu multi dan media. Multi berarti banyak dan media biasa diartikan alat untuk menyampaikan atau membuat sesuatu, perantara, alat pengantar, suatu bentuk komunikasi seperti surat kabar, majalah, atau televisi.

Berdasarkan pengertian tersebut dapat disimpulkan bahwa multimedia yang adalah suatu teknologi yang menggabungkan berbagai sumber media seperti teks, grafik, suara, animasi, video, dan sebagainya, yang disampaikan dan dikontrol oleh sistem.

Pengertian multimedia pembelajaran terbagi menjadi dua yaitu sebelum tahun 1980-an dan setelah tahun 1980-an. Sebelum tahun1980-an atau pada era 60-an, multimedia diartikan sebagai kumpulan dari berbagai peralatan media berbeda yang digunakan untuk presentasi. Sudatha (2015:21), menyatakan bahwa multimedia secara tradisional merujuk pada penggunaan beberapa media, sedangkan multimedia pada zaman sekarang merujuk kepada penggunaan gabungan beberapa media dalam peyajian pembelajaran melalui komputer.

Berdasarkan uraian definisi tersebut dapat disimpulkan bahwa multimedia pembelajaran adalah sistem komuikasi interaktif berbasis komputer dalam suatu penyajian secara terintegrasi. Istilah berbasis komputer berarti bahwa program multimedia menggunakan komputer dalam menyajikan pembelajaran. istilah terintegrasi berarti bahwa multimedia pembelajaran dapat menampilkan teks, gambar, audio, dan video atau animasi dalam satu kali tayangan presentasi.

Piaget, menyebutkan bahwa "kognitif adalah bagaimana anak beradaptasi dan menginterpretasikan objek dan kejadian-kejadian disekitarnya".Piaget memandang bahwa anak memainkan peranan aktif didalam menyusun pengetahuannya mengenai realitas, anak tidak pasif menerima informasi. Walaupun proses berpikir dan konsepsi anak mengenai realitas telah dimodifikasi oleh pengalamannya dengan dunia sekitar dia, namun anak juga aktif menginterpretasikan informasi yang ia peroleh dari pengalaman, serta dalam 
16 Pengembangan Etnosains multimedia learning untuk meningkatkan kognitif skill siswa sekolah dasarTio Gusti Satria, Asep Sukenda Egok

mengadaptasikannya pada pengetahuan dan konsepsi.

Dari berbagai penilaian yang telah disebutkan diatas dapat dipahami bahwa kognitif adalah sebuah istilah yang digunakan oleh psikolog untuk menjelaskan semua aktifitas mental yang berhubungan dengan persepsi, pikiran, ingatan, dan pengolahan informasi yang memungkinkan seseorang memperoleh pengetahuan, memecahkan masalah, dan merencanakan masa depan, atau semua proses psikogis yang berkaitan dengan bagaimana individu mempelajari, memperhatikan, mengamati, membayangkan, memperkirakan, menilai, dan memikirkan lingkungannya.

Piaget adalah seorang tokoh psikologi kognitif yang besar pengaruhnya terhadap perkembangan pemikiran para pakar kognitif lainnya. Menurut Piaget, perkembangan kognitif merupakan suatu proses genetik, yaitu suatu proses yang didasarkan atas mekanisme biologis perkembangan sistem syaraf. Piaget tidak melihat perkembangan kognitif sebagai sesuatu yang dapat didefinisikan secara kuantitatif. Ia menyimpulkan bahwa daya pikir atau kekuatan mental anak yang berbeda usia akan berbeda pula secara kualitatif.

Menurut Piaget, proses belajar seseorang akan mengikuti pola dan tahap-tahap perkembangannya sesuai dengan umurnya. Pola dan tahap-tahap ini bersifat hierarkis, artinya harus dilalui berdasarkan urutan tertentu dan seseorang tidak dapat belajar sesuatu yang berada di luar tahap kognitifnya. Piaget membagi tahaptahap perkembangan kognitif ini menjadi empat, yaitu:

Tahap Sensorimotor menurut Piaget dimulai sejak umur 0 sampai 2 tahun. Pertumbuhan kemampuan anak tampak dari kegiatan motorik dan persepsinya yang sederhana. Ciri pokok perkembangannya berdasarkan tindakan, dan dilakukan langkah demi langkah.

Piaget mengatakan tahap ini antara usia 2 - 7/8 tahun. Ciri pokok perkembangan pada tahap ini adalah pada penggunaan symbol atau bahasa tanda, dan mulai berkembangnya konsepkonsep intuitif. Tahap ini dibagi menjadi dua, yaitu preoperasional dan intuitif. Preoperasional (umur 2-4 tahun), anak telah mampu menggunakan bahasa dalam mengembangkan konsep nya, walaupun masih sangat sederhana. Maka sering terjadi kesalahan dalam memahami objek.

Ciri pokok perkembangan pada tahap ini adalah anak sudah mulai menggunakan aturanaturan yang jelas dan logis, dan ditandai adanya reversible dan kekekalan. Anak telah memiliki kecakapan berpikir logis, akan tetapi hanya dengan benda-benda yang bersifat konkret. Operation adalah suatu tipe tindakan untuk memanipulasi objek atau gambaran yang ada di dalam dirinya. Karenanya kegiatan ini memerlukan proses transformasi informasi ke dalam dirinya sehingga tindakannya lebih efektif. Anak sudah tidak perlu coba-coba dan membuat kesalahan, karena anak sudah dapat berpikir dengan menggunakan model "kemungkinan" dalam melakukan kegiatan tertentu. Ia dapat menggunakan hasil yang telah dicapai sebelumnya. Anak mampu menangani sistem klasifikasi.

Ciri pokok perkembangan pada tahap ini adalah anak sudah mampu berpikir abstrak dan logis dengan menggunakan pola berpikir "kemungkinan". Model berpikir ilmiah dengan tipe hipothetico-dedutive dan inductive sudah mulai dimiliki anak, dengan kemampuan menarik kesimpulan, menafsirkan dan mengembangkan hipotesa.

Keterampilan Kognitif erat kaitannya dengan Taksonomi Bloom. Taksonomi, menurut kamus besar Bahasa Indonesia mempunyai arti 
17 Pengembangan Etnosains multimedia learning untuk meningkatkan kognitif skill siswa sekolah dasarTio Gusti Satria, Asep Sukenda Egok

"klasifikasi bidang ilmu; kaidah dan prinsip yang meliputi pengklasifikasian objek”. Taksonomi Bloom sendiri adalah taksonomi dalam bidang kependidikan yang dicetuskan oleh Benjamin

S. Bloom. Taksonomi ini bertujuan untuk mengklasifikasikan materi atau tujuan dari pendidikan. Misalnya tujuan pendidikan antara peserta didik di SMA, SMK, antara SD dengan SMP seperti itu. Secara garis besar, tujuan pendidikan dibagi dalam 3 domain yang masingmasing domain mempunyai sub-tujuan sendirisendiri. 3 domain dalam tujuan pendidikan tersebut adalah:

Domain kognitif berisi perilaku-perilaku yang menekankan aspek intelektual seperti pengetahuan, pengertian dan keterampilan berpikir. Domain Afektif Domain afektif menekankan pada aspek perasaan dan emosi seperti minat, sikap, apresiasi dan adaptasi.Domain Psikomotorik domain psikomotorik berisi perilaku-perilaku yang menekankan aspek keterampilan motorik seperti menulis, mengetik, olahraga

\section{BLOOMS TAXONOMY}

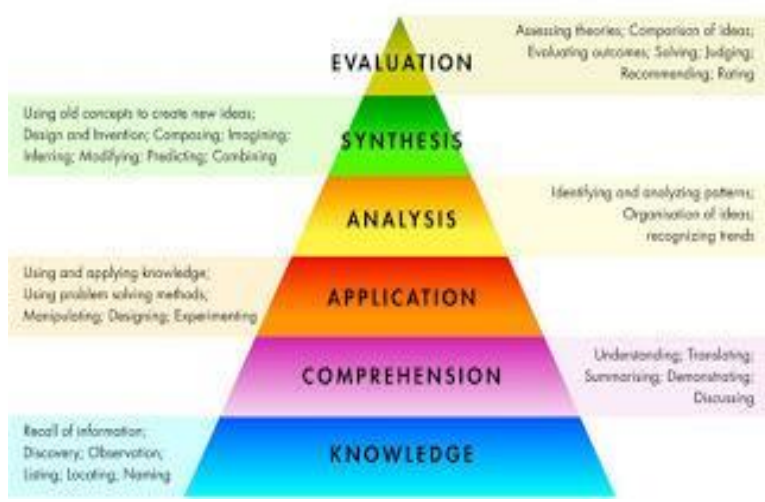

Taksonomi Bloom Domain Kognitif

\section{METODE}

Penelitian ini adalah penelitian kepustakaan atau library research. Penelitian ini bertujuan untuk mengkaji teks, buku-buku dan naskah publikasi mengenai gaya dan strategi belajar bahasa. Kajian ini diambil dari naskah-naskah kepustakaan yang relevan dengan topik penelitian yaitu berkaitan dengan topik yang dibahas. Sumber data yang digunakan adalah data-data hasil penelitian terdahulu yang relevan. Langkahlangkah yang dilakukan diantaranya pengumpulan data pustaka, membaca, mencatat, serta membandingkan literatur untuk kemudian diolah dan menghasilkan kesimpulan. Data yang digunakan merupakan data skunder berasal dari teksbook, jurnal, article ilmiah dan literature review yang berisikan tentang konsep yang sedang dikaji.

\section{HASIL DAN PEMBAHASAN}

Langkah yang di lakukan pada pengembangan media ini adalah pertama tahap perencanaan, kedua tahap pengembangan dan ketiga tahap evaluasi, pada tahap pengembangan ini ada tiga hal yang harus dianalisis yaitu (1) analisis kebutuhan, (2) analisis karakteristik peserta didik, dan (3) analisis materi pembelajaran.

Penelitian pendahuluan dilakukan dengan cara pengamatan pada kelas lima saat melakukan pembelajaran IPA. berdasarkan pengamatan peneliti bahwa suasana kelas kurang efektif karena pembelajaran berlangsung masih bersifat satu arah dan mengandalkan guru sebagai satu satunya sumber informasi. Dalam menyampaikan informasi atau materi yang bersifat abstrak hanya dijelaskan dengan menggunakan media gambar sederhana, sedangkan peserta didik membutuhkan penjelasan yang lebih konkret agar mampu memahami materi-materi tersebut.

Buku yang digunakan dirasa kurang
menarik perhatian $\begin{array}{rr}\text { siswa, buku yang } \\ \text { digunakan oleh siswa berisi materi yang terlalu }\end{array}$


18 Pengembangan Etnosains multimedia learning untuk meningkatkan kognitif skill siswa sekolah dasarTio Gusti Satria, Asep Sukenda Egok

minim, gambar yang terdapat di dalam buku monoton, dan soal-soal terdiri dari pilihan ganda, dimana kebanyakan siswa hanya memilih tanpa berusaha untuk mencari jawaban oleh sebab itu siswa cenderung kurang termotivasi hal ini terlihat ketika peneliti mengadakan observasi ketika proses pembelajaran berlangsung banyak siswa yang tidak fokus di dalam proses belajar.

Analisis karakter peserta didik pada SD IT

Raudhatul Jannah Kota Lubuklinggau bahwa tingkat usianya antara 11-12 tahun. Kemampuan rata-rata peserta didik dalam katagori tingkat tinggi, sedang dan rendah, hal ini dilihat dari hasil belajar dalam satu semester. Untuk tingkat ekonomi rata-rata pekerjaan orangtua $60 \%$ pegawai negeri, $10 \%$ swasta, $30 \%$ lainnya. Hasil pengamatan peneliti untuk kecakapan dasar yang dimiliki oleh peserta didik antara lain: (a) peserta didik mampu mengoperasikan komputer, (b) peserta didik dapat menyimpan data di komputer dan (c) peserta didik dapat mengetik serta mengedit data di komputer. Peserta didik menjadi lebih bersemangat jika proses pembelajaran dilaksanakan dengan menggunakan media komputer. Dengan banyaknya materi pelajaran yang perlu divisualisasikan, peserta didik merasa kesulitan untuk memahami materi pelajaran khususnya tanpa dibantu dengan bahan ajar yang tepat dan dapat memperjelas materi yang disampaikan serta dapat memotivasi peserta didik untuk belajar lebih aktif.

Berdasarkan hasil analisis kebutuhan di atas dapat disimpulkan bahwa dibutuhkan inovasi baru di dalam proses belajar mengajar sehingga membuat siswa lebih termotivasi dalam proses pembelajaran IPA. Berdasarkan pengamatan peneliti di lapangan peserta didik sangat antusias jika proses pembelajaran menggunakan teknologi komputer, hal ini dikarenakan peserta didik lebih termotivasi jika proses pembelajaran menggunakan teknologi komputer sehingga mereka bisa menyalurkan minat dan bakat mereka di dalam mengespresikan kemampuan teknologi yang mereka miliki, hal ini menjadi pertimbangan untuk peneliti agar membuat bahan ajar yang bisa digunakan oleh peserta didik dengan mengembangkan minat dan bakat mereka. Oleh karena itu peneliti mengembangkan Etnosains Multimedia Learning pada Pembelajaran IPA di SD IT Raudhatul Jannah.

Produk awal multimedia ini diawali dengan mendesain Etnosains Multimedia Learning IPA dengan pokok bahasan Siklus Hujan tersebut ke dalam bentuk computer based. Desain pembelajaran Etnosains Multimedia Learning IPA dengan pokok bahasan Siklus Hujan yang telah dibuat oleh peneliti dalam bentuk paper based diwujudkan dalam bentuk computer based yang terdiri dari pemprograman dasar, pembuatan grafis, pembuatan animasi, pembuatan narasi.

Program yang digunakan peneliti untuk mendesain Etnosains Multimedia Learning dalam bentuk computer based adalah Macromedia Flash 8. Program ini dapat digunakan dalam perancangan perangkat lunak dengan navigasi dan desain yang sangat menarik. Sehingga dapat membantu keinginan peneliti dalam membuat Etnosains Multimedia Learning IPA dengan pokok bahasan Siklus Hujan.

Model draft I multimedia interaktif diberikan kepada expert review tahap ini bertujuan untuk mendapatkan Etnosains Multimedia Learning IPA yang valid. Dari hasil validasi ahli materi diperoleh saran berupa; materi masih perlu direvisi dan perlu dilengkapi lagi; pada penulisan (ejaan, huruf dan tanda baca) perlu diperhatikan; dan tingkat kesukaran soal harus disesuaikan. Hasil validasi ahli materi dapat dilihat pada tabel 1 berikut: 
19 Pengembangan Etnosains multimedia learning untuk meningkatkan kognitif skill siswa sekolah dasar Tio Gusti Satria, Asep Sukenda Egok

Tabel 1. Validasi ahli materi

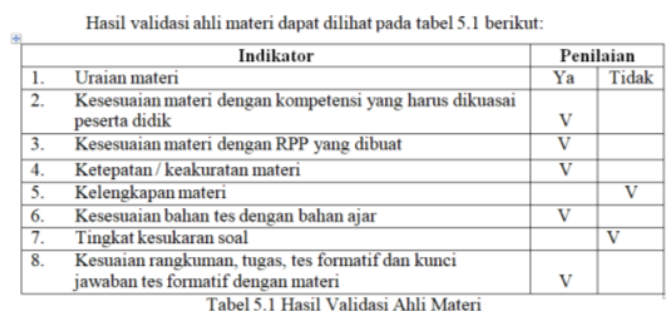

Pada tabel 1 di atas terdapat delapan indikator yang dinilai oleh expert review bidang materi, penilaian yang diberikan pada setiap indikator adalah Ya yaitu indikator yang tertulis tersebut terdapat di dalam Etnosains Multimedia Learning pada Siklus Hujan yaitu; (1) Uraian materi, pada aspek ini uraian materi telah disesuaikan dengan materi Siklus Hujan; (2) Kesesuaian materi dengan kompetensi yang harus dikuasai peserta didik, pada aspek ini materi telah sesuai dengan kompetensi; (3) Kesesuaian materi dengan RPP yang dibuat, pada aspek ini materi telah sesuai dengan RPP; (4) Ketepatan / keakuratan materi, (5) Kelengkapan materi, pada penyajian materi pada multimedia adanya tulisan, gambar, animasi dan video; (6) Kesesuaian bahan tes dengan bahan ajar, pada indikator ini tes yang dibuat disesuaikan dengan materi pelajaran; (7) Tingkat kesukaran soal, dan (8) Kesuaian rangkuman, tugas, tes formatif dan kunci jawaban tes formatif dengan materi.

Model draft I multimedia interaktif juga divalidasi oleh ahli media. Expert review memberikan komentar dan saran sebagai berikut yaitu; pada latihan sebaiknya siswa mengetahui hasil latihan pada bagian mana yang masih harus diperbaiki, pada multimedia ini sebelumnya belum terdapat nilai atau skor yang diperoleh siswa jika telah menyelesaikan soal latihan; Soal latihan dapat diulang kembali hingga penguasaan siswa maksimal; Warna sumber dan teks harus kontras. Hasil validasi ahli materi dapat dilihat pada tabel 2 di bawah ini:
Tabel 2. Validasi Ahli

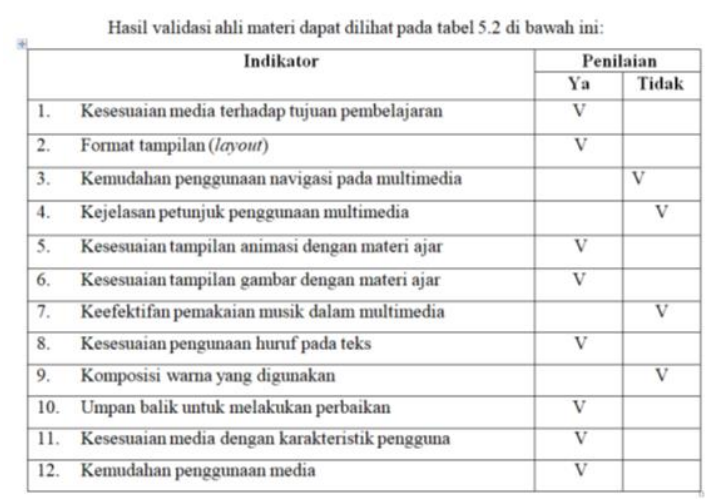

Pada tabel 5.2 di atas terdapat delapan indikator yang dinilai oleh expert review

Pada tabel 2 di atas terdapat delapan indikator yang dinilai oleh expert review bidang media, penilaian yang diberikan pada setiap indikator adalah Ya yaitu indikator yang tertulis tersebut terdapat di dalam Etnosains Multimedia Learning pada materi Siklus Hujan yaitu; (1) Kesesuaian media terhadap tujuan pembelajaran, pada aspek tujuan pembelajaran sesuai dengan media yang dibuat; dalam (2) Format tampilan (layout), pada aspek ini layout yang ada pada multimedia telah sesuai, dalam hal ini telah sesuai antara warna background dengan warna tulisan dan sudah kontras; (3) Kemudahan penggunaan navigasi pada Multimedia Interaktif, pada aspek ini penyajian navigasi belum sesuai dengan tampilan multimedia yang dibuat, sebab masih terdapat beberapa navigasi yang setelah di klik belum berfungsi dengan baik, sehingga perlu dilakukan revisi pada indikator ini; (4) Kejelasan petunjuk penggunaan Multimedia Interaktif, pada aspek ini petunjuk untuk menggunakan multimedia sudah sesuai, hanya terdapat kekurangan pada bahasa yang digunakan dalam petunjuk penggunaan belum menggunakan bahasa yang mudah dimengerti oleh user / siswa, oleh karena itu, perlu direvisi; (5) Kesesuaian tampilan animasi dengan materi ajar, pada indikator ini penyajian animasi sudah sesuai dengan materi, hal ini terlihat dari gambar- gambar animasi yang di tampilkan sudah sesuai dengan judul materi yang dibahas; (6) Kesesuaian tampilan gambar dengan materi ajar, 
20 Pengembangan Etnosains multimedia learning untuk meningkatkan kognitif skill siswa sekolah dasar Tio Gusti Satria, Asep Sukenda Egok

penyajian gambar pada multimedia telah sesuai dengan materi sistem organ mahkluk hidup; (7) Keefektifan pemakaian musik dalam Multimedia Interaktif, pada penyajian musik belum dalam kategori efektif, sebab untuk penggunaan musik harus disesuaikan dengan siapa user/siswa yang menggunakan, berikan pilihan agar siswa dapat memilih volume suara yang mereka inginkan; (8) Kesesuaian penggunaan huruf pada teks, pada aspek ini penggunaan huruf dan teks telah sesuai dan mempermudah saat membaca materi; (9) Komposisi warna yang digunakan, komposisi warna yang digunakan telah disesuaikan dengan background multimedia dan teks harus kontras; (10) Umpan balik untuk melakukan perbaikan, dalam hal umpan balik ini adalah mengukur interaktif siswa. Umpan balik ini berupa latihan yang sebaiknya siswa mengetahui hasil latihan, dan pada bagian mana yang masih harus diperbaiki; (11) Kesesuaian media dengan karakteristik pengguna sudah ada, hal ini terlihat dari komponen-komponen dalam multimedia yang telah disesuaikan berdasarkan karakteristik user / siswa; (12) Kemudahan menggunakan media sudah ada, terlihat dari adanya petunjuk penggunaan multimedia yang memudahkan siswa untuk menggunakan Etnosains Multimedia Learning.

Produk yang telah diperbaiki berdasarkan hasil validasi ahli materi, ahli media dan ahli desain pembelajaran selanjutnya akan digunakan untuk uji coba kelompok kecil. Pada uji coba one to one evaluation ini, instrument pengumpulan data berupa lembar wawancara.
Tabel 3 Komentar dan Saran Peserta didik Pada Tahap One to One

Tabel 5.3 Komentar dan Saran Peserta didik Pada Tahap One to One

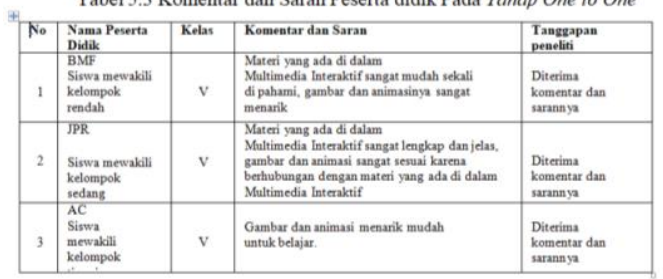

Berdasarkan hasil one to one evaluation dan observasi langsung dengan tiga siswa terlihat peserta didik BMF, JPR, dan AC mengalami kemudahan dalam menggunakan Etnosains Multimedia Learning, peserta didik tersebut cepat mengerti cara mengoperasikan tiap-tiap bagian yang ada di multimedia, pemahaman dalam materi yang tadinya bersifat abstrak kini jadi lebih dapat divisualisai siswa dengan melihat gambar animasi dan video secara langsung, gambar dan animasi yang menarik membuat siswa tersebut lebih tertarik dalam mempelajari tiap materi.

Berdasarkan dari hasil expert review dari kesulitan yang dialami guru dan peserta didik (one to one evaluation) pada saat uji coba pada prototype pertama dijadikan dasar untuk merevisi prototype pertama menjadi prototype kedua, kemudian diujicobakan pada small group yaitu pemberian Etnosains Multimedia Learning IPA dengan pokok bahasan Siklus Hujan yang telah direvisi (prototype kedua) kepada sepuluh orang siswa Sekolah Dasar IT Raudhatul Jannah yang tidak ikut uji coba one to one evaluation.

\section{SIMPULAN}

Pembelajaran sains yang mampu menjembatani perpaduan antara budaya siswa atau pengetahuan asli dengan budaya ilmiah di sekolah atau pengetahuan khas dari suatu komunitas atau etnosains dapat mengefektifkan proses belajar siswa. Siswa belajar secara formal untuk memahami lingkungannya dengan berbagai permasalahan yang ada di sekitarnya. cara 
21 Pengembangan Etnosains multimedia learning untuk meningkatkan kognitif skill siswa sekolah dasar Tio Gusti Satria, Asep Sukenda Egok

mengajar guru yang sering menggunakan metode ceramah, text book centered dan jarang menggunakan media pembelajaran. Sedangkan, siswa membutuhkan penjelasan dari guru dalam bentuk nyata, akan tetapi karena guru tidak menggunakan media pembelajaran yang dapat menarik minat siswa dalam belajar. media pembelajaran mencakup manusia, materi atau kajian yang membangun suatu kondisi yang membuat siswa mampu memperoleh pengetahuan, keterampilan atau sikap. Media pembelajaran diharapkan untuk menyampaikan atau menyalurkan pesan dari suatu sumber secara terencana kepada siswa, sehingga terjadi lingkungan belajar yang kondusif dimana peserta didik dapat melakukan proses belajar secara efisien dan efektif. Multimedia Learning diharapkan mampu meningkatkan kognitif skill siswa dan pembelajaran menjadi lebih bermakna

\section{DAFTAR PUSTAKA}

Ahimsa-Putra, Heddy Shri. 1985. Etnosains dan Etnometodologi Sebuah Perbandingan dalam Masyarakat Indonesia Majalah IlmuIlmu Sosial Indonesia, Jilid XII (2) hal: 103-132. Jakarta: Lembaga Ilmu Pengetahuan Indonesia. Arsyad, A. 2007. Media Pembelajaran. Jakarta: Raja Grafindo Persada

Pradesa, Ni Made Mas Yoni. Dkk. 2014. Pengembangan Multimedia Pembelajaran Interaktif Berbasis Flash Mata Pelajaran PKn Kelas VI SD. EJournal Edutech Universitas Pendidikan Ganesha Jurusan Teknologi Pendidikan. Vol: 2 No: 1 Tahun 2014

Pujiastuti, Desy. Dkk. 2014. Pengembangan Media Pembelajaran PKn Berbasis Multimedia Interaktif Untuk SMP Kelas VIII. Jurnal Tekno Pedagogi Universitas Jambi. Vol: 4 No. 1 Tahun 2014.

Rifa'i, Achmad dan Chatharina Tri Anni. 2010. Psikologi Pendidikan. Semarang: Unnes Press

Rosyidah, Anis Nur., Sudarmin, dan Kusnoro, S. 2013. Pengembangan Modul IPA
Berbasis Etnosains Zat Aditif Dalam Bahan Makanan Untuk Kelas VIII SMP Negeri 1 Pegandon Kendal. USEJ. ISSN2252-6609. Vol. 2 (1): 133- 139.

Sudhata, I Gde Wawan \& Tegeh, I Made. 2015. Desain Multimedia Pembelajaran .Yogyakarta: Media Akademi. 